\title{
PORT-SAID ENGINEERING RESEARCH JOURNAL
}

Faculty of Engineering - port said university

Volume $22 \quad$ No. $2 \quad$ September 2018 pp: 8:18

\section{Impact Assessment of Radial Channels Project on Water Quality Status in Lake Manzala, Eastern Nile Delta, Egypt}

\begin{abstract}
Ashraf El-Hamaimi ${ }^{1}$, Ahmed Mirdan ${ }^{2}$, Mohamed Elshemy ${ }^{3}$ and Ahmed Hassan ${ }^{4}$

Lake Manzala lies on the eastern north coast of Egypt and is considered as the largest Egyptian coastal lakes. Economically, Lake Manzala is considered as one of the most valuable fish sources in Egypt. The water quality status of the lake has been degraded due to the progressive increasing of industrial, municipal and agricultural wastewater discharge from six main drains. The lake has three main effective outlets, one to Suez Canal and the others to the Mediterranean Sea. A new project has been started in Lake Manzala to improve the sea-lake water exchange by dredging the two main lake outlets to the sea and constructing two radial channels from the lake to the sea passing through the two main outlets. In this work, a hydrodynamic, advection dispersion and water quality model for Lake Manzala was developed, based on MIKE21 modelling system. Eight water quality parameters were simulated (BOD, DO, Chll_a, $\mathrm{NO}_{2}, \mathrm{NO}_{3}, \mathrm{NH}_{3}, \mathrm{PO}_{4}$, and TP), in addition to three hydrodynamic parameters (water depth, water temperature and salinity). The model results show good agreement with the observed water depth, water temperature, salinity and water quality records. The calibrated model was used to investigate the impacts of radial channels on Lake Manzala hydrodynamic and water quality characteristics. The results show a significant improvement in the lake water quality status. Significant decreases in the average concentrations of some water quality parameters were noticed, comparing to the original calibrated status of the lake $\left(-21 \%,-14 \%,-13 \%\right.$ and $-10 \%$ for $\mathrm{PO}_{4}, \mathrm{NO}_{2}, \mathrm{NH}_{3}$ and $\mathrm{Chll}_{-} \mathrm{a}-$ as examples). While an increase in the average concentration of DO in the lake by about $1 \%$ was noticed. Other water quality improvement scenarios for the lake should be investigated, in addition to the investigated scenario of radial channels, using the lake developed model.
\end{abstract}

Keywords: Lake Manzala, MIKE21, Radial Channels, Water Quality Management.

\section{INTRODUCTION}

The spoilage of water quality and water's natural balance in its environment are known as water pollution [1]. Water pollution is considered as one of the most dangerous hazards which is affecting not only in Egypt but also in the majority of world countries.

Among the Egyptian coastal lakes, Lake Manzala is considered as the largest of the Egyptian shallow coastal lakes on the fringe of the Mediterranean Sea, Figure 1. The lake is located in the Northern-Eastern region of Egypt, surrounded by five provinces and represents an important source of inexpensive fish for human consumption in Egypt, it contributed by about $35 \%$ of the total country yield during the 1980's [2]. In the present, it is considered as the most productive lake in Egypt and contributed by about 44\% (2004-2013) and increased to about 56\% in 2013 from the total annual production of the northern Delta lakes [3]. The lake also provides important habitats for a variety of wildlife and is considered as a feeding area for migrating birds and endangered bird species. The aquatic health of the lake has been deteriorated due to increased contamination by polluted inflows and over intensive aquaculture. The lake receives about 5.5 $\mathrm{BCM} / \mathrm{year}$ of fresh water through five main drains; Bahr El-Baqar, Hadous, El-Serw, Mataria, and Faresquer drains [4]. These drains carry agricultural drainage, industrial wastes and municipal waste from 6 governorates; Cairo, El-Qalubia, Port Said, Demietta, El-Daqahlia and El-Sharqia. These drains have caused severe contamination to the lake by discharging huge amounts of heavy metals and other toxic materials which contaminate the whole aquatic environment. These toxins appear at high concentrations in water, sediment and fish leading to major health problems in the lake area [5]. The lake has only 2 effective and direct connections to the sea and one connection to the Suez Canal, in addition to some indirect ineffective connections to the sea as ElBoghdady and Eldiba. Lake Manzala has gradually transformed, with time, from a brackish environment to eutrophic fresh water [7]. Due to the lake importance, many investigations were carried out on Lake Manzala [8 - 9].

\footnotetext{
${ }^{1}$ Ministry of Water Resources and Irrigation, Cairo, Egypt (Email: a_elhamaimi@yahoo.com)

${ }^{2}$ Civil Engineering Department, Faculty of Engineering, Port Said University, Port Said, Egypt (Email:

a_mirdan@yahoo.com)

3Irrigation and Hydraulics Department, Faculty of Engineering, Tanta University, Tanta, Egypt, (Email: m.elshemy@feng.tanta.edu.eg)

${ }^{4}$ Irrigation and Hydraulics Department, Faculty of Engineering, Ain Shams University, Cairo, Egypt, (Email: ahmad9657@yahoo.co.uk).
} 


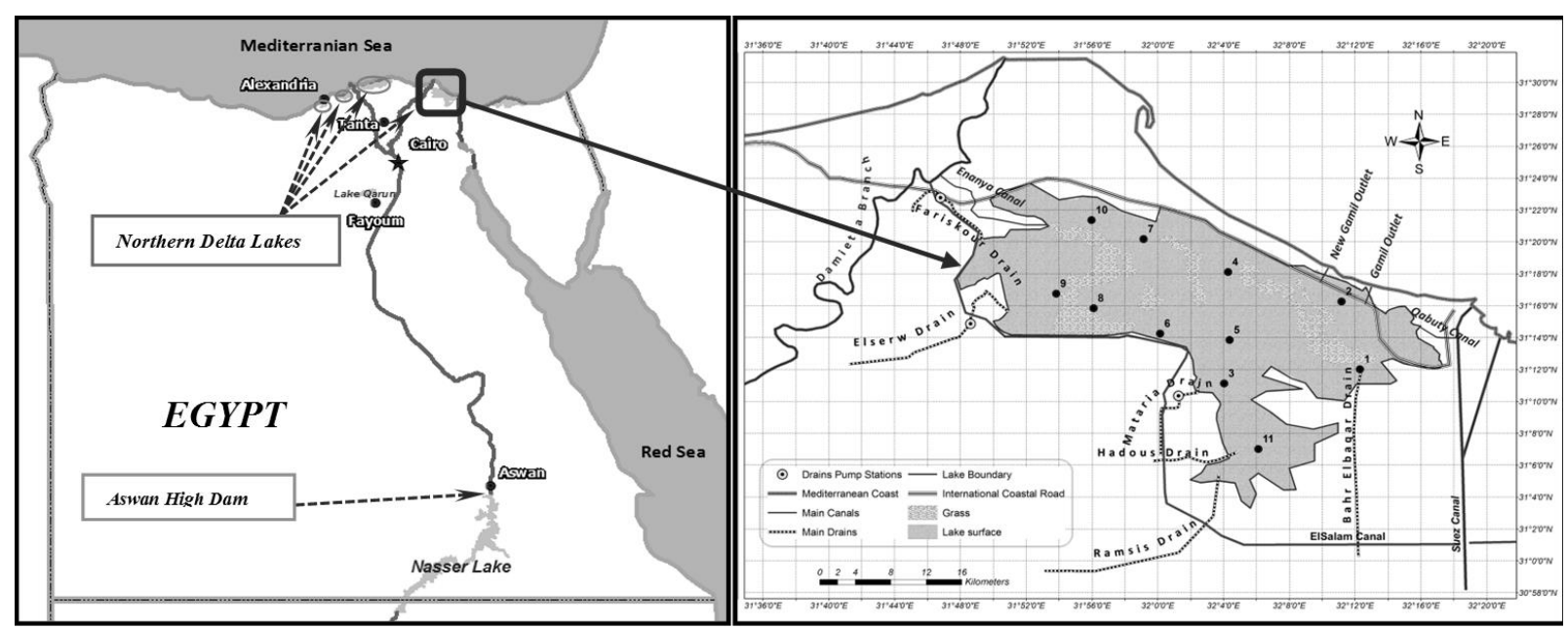

Figure 1: Lake Manzala layout and its field water quality record stations and drains [6]

The previous studies admit that the major problems of the lake can be summarized as following:-

1- The increase in the nutrients loading into the lake especially from the input drains that accelerate the eutrophication process occurring within the lake.

2- The increase in heavy metal concentrations through the lake including $\mathrm{Cu}, \mathrm{Cd}, \mathrm{Pb}, \mathrm{Hg}, \mathrm{Zn}$ and $\mathrm{Mn}$ in water, sediments and fish.

3- The lake is contaminated with high amount of TVB (total viable bacteria) and FCB (fecal coliform bacteria).

4- Fish are contaminated on surface and internally tissues with a very high amount of TVB and FCB and recent studies admit that "the fish is highly polluted and dangerous for human health" [9].

5- The lack of lake outlets.

6- The lake turns to small basins due to fish farms.

Lake Manzala was selected to be one of nine primary sites of North Africa wetlands to be biodiversity studied within the CASSARINA Project [12] and one of three studied cases in the southern Mediterranean region for the MELMARINA Project [13]. Thompson et al. [4] investigated the hydrological and water quality status of the lake through MELMARINA Project and reported that the tidal oscillations in water levels are not extending throughout the lake due to the vegetated islands within the lake which are due to the influence of drainage inflows. The developed hydrodynamic and water quality models on Lake Manzala are very scarce, despite of the large previous studies carried out on the lake. In 2009, Rasmussn et al. [14] had developed a hydrodynamic-ecological model for Lake Manzala, based on MIKE 21, to analyze the development of water quality as a function of the load of organic material and nutrients. Bek et al. [15], in 2011, constructed a hydrodynamic model for the lake using the Finite Volume Coastal Ocean Model (FVCOM) to characterize the hydrodynamics characteristics of the lake and to assess the application of a range of potential sustainable water management strategies. In 2016, Elshemy et al. [6] had developed a hydrodynamic and water quality model for Lake
Manzala using MIKE21 modelling system and this developed model was used to study the future impacts of climate change on the hydrodynamic characteristics of the lake [16].

The main objective of this research work is to develop a hydrodynamic, advection dispersion and water quality model for Lake Manzala and to use this model to investigate the impacts of Radial Channels project on the water quality status of Lake Manzala.

\section{MATERIALS AND METHODS}

\subsection{Study Area}

Lake Manzala, the largest Egyptian costal lakes, lies on the eastern boundary of the Nile Delta. It is about 47 $\mathrm{km}$ long and $30 \mathrm{~km}$ wide and is classified as a shallow lake; its water depth ranges from 0.7 to $1.5 \mathrm{~m}$. the lake water salinity is ranges from low salinity in the south and west to brackish water over the most of its area to saline water in the extreme north east [17]. About 23\% of the lake total area is islands [18], Figure 1 shows the layout of the lake. Table 1 presents the lake general characteristics. The lake has three connections to the sea (outlets), two of them are effective, in addition to a very narrow canal (El-Qabuty Canal) connects the lake to Suez Canal at the east while the northern boundary of the lake is the Mediterranean Sea. The main outlets are El-Gamil 1 and the New El-Gamil 2 outlets. These outlets improve the water quality status of the lake due to lake-sea water exchange. Lake Manzala receives agricultural, industrial and domestic wastes through a lot of drains such as, Fareskour, El-Serw, Hadous and Bahr El-Baqar, typical flow discharges of these drains can be seen in Figure 2 [4]. The lake pollution comes from many sources, human activities such as land cultivation, drains polluted inflows, human settlements and few lake outlets. These pollutants are transformed the lake water quality status from a marine estuary environment to a eutrophic freshwater system composed of about 30 basins which are varying in their hydrological and water quality characteristics (Rashad and Abdel-Azeem 2010) [17]. 
Table 1: General characteristics of Lake Manzala.

\begin{tabular}{|l|l|}
\hline Location & $31^{\circ} 45^{\prime}-32^{\circ} 15 \mathrm{E}, 31^{\circ} 00^{\prime}-31^{\circ} 30 \mathrm{~N}$ \\
\hline Area & $600 \mathrm{~km}$ \\
\hline Lake classification & Brackish \\
\hline Average - and maximum depth & $1 \mathrm{~m}-3.5 \mathrm{~m}$ \\
\hline Average sediment accumulation rate & $1.9-2.2 \mathrm{~kg} / \mathrm{m}^{2} / \mathrm{Yr}$. \\
\hline Annual precipitation & $78.4 \mathrm{~mm} / \mathrm{Yr}$. \\
\hline Annual evaporation & $1100.2 \mathrm{~mm} / \mathrm{Yr}$. \\
\hline Suspended particulate matter & $129-261 \mathrm{mg} / \mathrm{m}^{3}$ \\
\hline Zooplankton No. & $1212 \times 10^{3}$ animals $/ \mathrm{m}^{3}$ \\
\hline
\end{tabular}

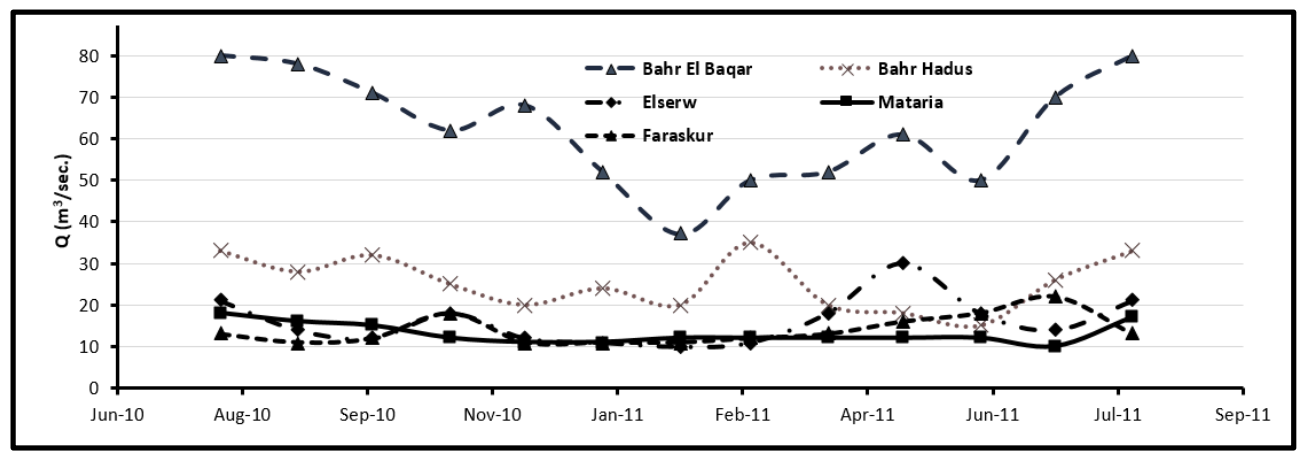

Figure 2: Drains inflow in Lake Manzala (from Aug. 2010 to Aug. 2011) [4]

\subsection{Radial Channels Project}

There is a new water quality management project, under construction, to improve the operation of the main two outlets of Lake Manzala (El-Gamil 1 and ElGamil 2) [19]. The project consists of three stages, the first stage is dredging a basin in front of each outlet (in the sea side) to a bed level of (-2.50) $\mathrm{m}$, as shown in
Figures 3, 4 and 5. The second stage is dredging the outlet itself from the basin to the lake at a bed level of (-3.00). The third stage is constructing a channel of three kilometers long from the outlet to inside the lake at a bed level of $(-3.00)$ to increase the water exchange between Lake Manzala and the Mediterranean Sea.

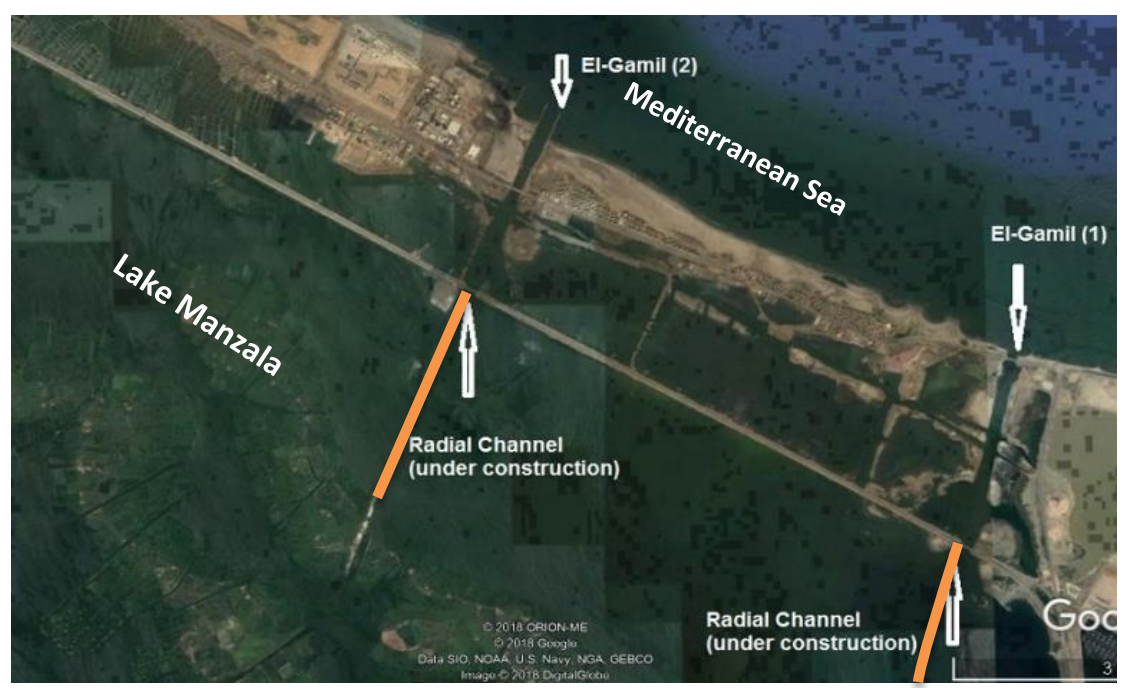

Figure 3: Layout of Radial Channels Project in Lake Manzala 


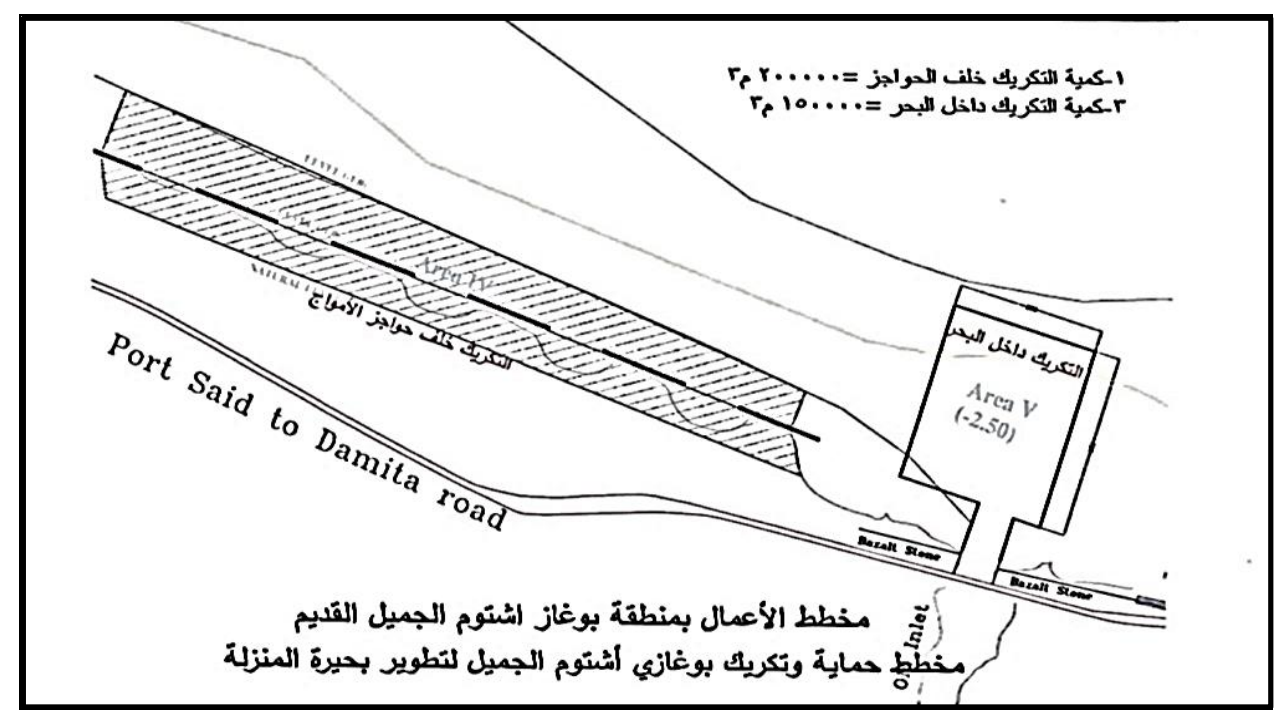

Figure 4: Layout of El-Gamil 1 Outlet works, $1^{\text {st }} . \& 2^{\text {nd }}$. Phase. [19]

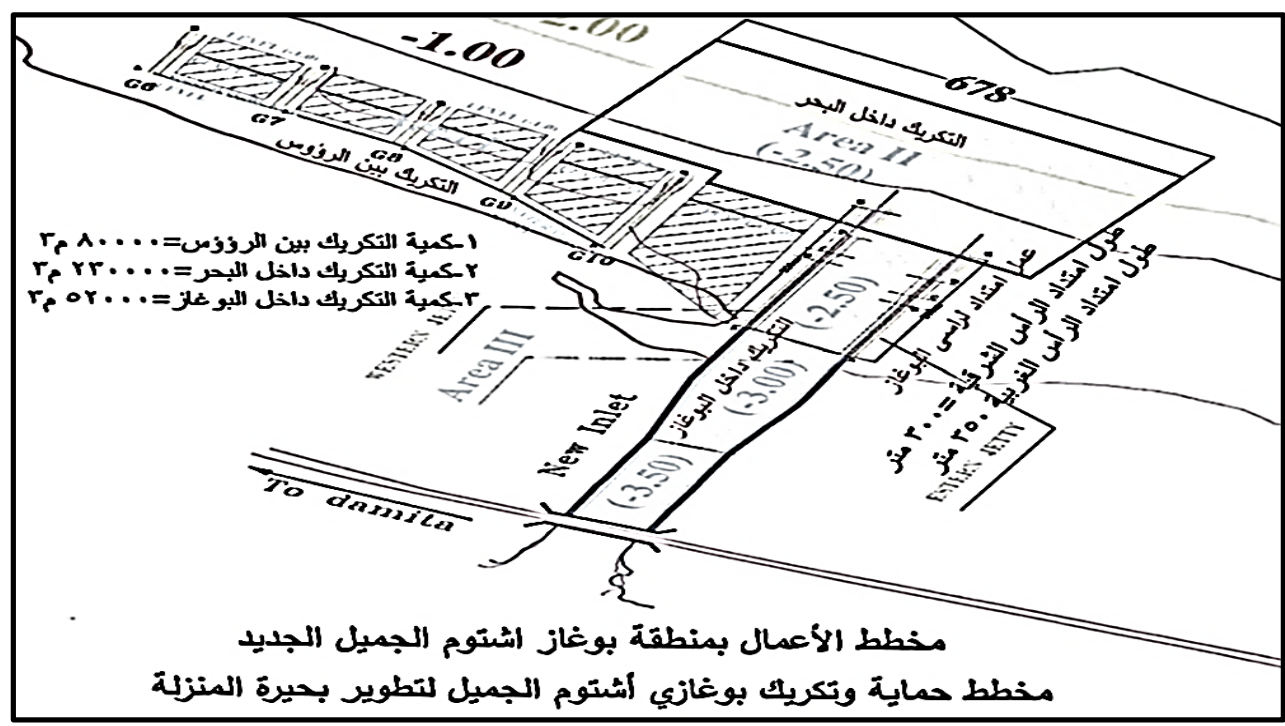

Figure 5: Layout of El-Gamil 2 Outlet works, $1^{\text {st }} \& 2^{\text {nd }}$ stages. [19]

\subsection{Data Collection}

The Egyptian Environmental Affairs Agency (EEAA) has assigned eleven record stations in Lake Manzala for collecting physical, chemical and biological records, Figure 1. Hydrodynamic and water quality parameters were seasonally collected in August, November, February and May for two successive years (from August 2010 to August 2012). These data are statistically summarized in Tables 2 for the lake and Table 3 for the drains. Hydrological records and drain discharges were collected by National Water Research Center (NWRC), Egypt, Figure 2. Water depths and water levels were collected from five stations in the lake, as shown in Figure 6. The wind speed main direction is North and western-North and ranges from 10 to $40 \mathrm{~km} / \mathrm{hr}$. Meteorological data were obtained from the internet (Weather Underground [20] and Info space [21]) at Port Said Airport station which is considered as the nearest meteorological stations to the lake and lies at the north-eastern corner of the lake.

\subsection{Model Development}

\subsubsection{MIKE21 Code Description}

MIKE 21 Flow Model is a two-dimensional, depth averaged, general numerical modelling system for freesurface flow. It is applicable to the simulation of hydraulic and environmental phenomena in lakes, estuaries, bays and coastal areas. It simulates unsteady two- dimensional flows in one layer (vertically homogeneous) and has been applied in a large number of studies [22 - 29]. This code contains three modules, hydrodynamic (HD) (for velocities and water levels), advection-dispersion (AD) (for thermal and conservative simulation such as water temperature and salinity) and ECO Lab (for water quality simulation). 


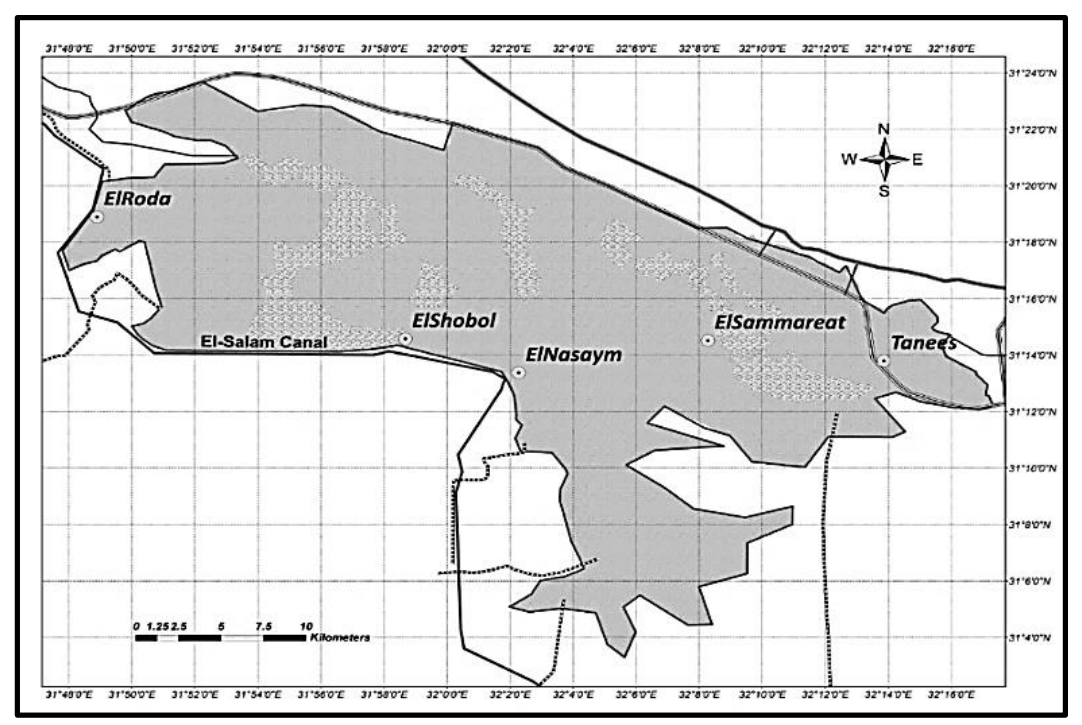

Figure 6: Water levels recording stations in Lake Manzala

Table 2: Statistical summary of water quality data for Lake Manzala (Aug 2010 - Aug 2012)

\begin{tabular}{|l|l|l|l|l|l|l|l|l|l|}
\hline Parameter & Unit & Min & Max & Mean & Parameter & Unit & Min & Max & Mean \\
\hline Temp & ${ }^{\circ} C$ & 12.70 & 30.6 & 23.12 & COD & $m g / L$ & 6.40 & 660.27 & 135.94 \\
\hline EC & $\mu S / c m$ & 1.50 & 30.29 & 7.23 & TN & $m g / L$ & 0.57 & 19.56 & 4.56 \\
\hline TSS & $g / L$ & 1.24 & 18.81 & 4.1 & TP & $m g / L$ & 0.024 & 2.01 & 0.49 \\
\hline pH & - & 7.00 & 9.40 & 8.30 & Nitrate & $m g / L$ & 0.001 & 0.33 & 0.051 \\
\hline DO & $m g / L$ & 0.00 & 26.54 & 6.61 & Phosphate & $m g / L$ & 0.005 & 0.90 & 0.22 \\
\hline BOD & $m g / L$ & 0.58 & 218.7 & 21.85 & Chll_a & $m g / L$ & 0.002 & 0.39 & 0.045 \\
\hline
\end{tabular}

Table 3: Statistical summary of Av. water quality data for Lake Manzala drains (Aug 2010 - Aug 2012)

\begin{tabular}{|l|l|l|l|l|l|}
\hline Parameter & Unit & Min & Max & Mean & SD \\
\hline Temp & ${ }^{\circ} \mathrm{C}$ & 12.70 & 29.87 & 23.05 & 5.26 \\
\hline EC & $\mu S / c m$ & 0.85 & 5.69 & 2.18 & 1.40 \\
\hline TSS & $m g / L$ & 23.25 & 137.0 & 62.31 & 27.94 \\
\hline pH & - & 7.05 & 8.39 & 7.99 & 0.35 \\
\hline DO & $m g / L$ & 0.00 & 7.28 & 2.00 & 1.79 \\
\hline BOD & $m g / L$ & 4.09 & 213.8 & 49.64 & 52.49 \\
\hline COD & $m g / L$ & 4.35 & 448.0 & 96.36 & 117.7 \\
\hline TN & $m g / L$ & 2.05 & 17.41 & 6.30 & 3.31 \\
\hline TP & $m g / L$ & 0.37 & 2.10 & 0.92 & 0.45 \\
\hline Nitrate & $m g / L$ & 0.07 & 2.08 & 0.53 & 0.45 \\
\hline Phosphate & $m g / L$ & 0.16 & 1.08 & 0.44 & 0.23 \\
\hline Chll_a & $\mu g / L$ & 1.74 & 99.90 & 24.10 & 26.47 \\
\hline
\end{tabular}

\subsubsection{Model Development for Lake Manzala}

A hydrodynamic and water quality model for Lake Manzala has been developed and calibrated by Hassan et al. in 2018 [30] and was modified in this study to investigate the impacts of Radial Channels Project on the water quality status of the lake. The modeling process included three depended phases (a HD model, an AD model and an Eco-Lab model). The lake model developing has been done on three dependent stages.
The hydrodynamic model (HD) was developed and calibrated using the water levels field records at the five water level stations. The AD model was developed, based on the calibrated HD model. Two parameters were simulated, water temperature and salinity. The developed AD model was calibrated using the lake field records of the water temperature and salinity at the eleven record stations for water quality of the lake. The Eco-Lab model was developed based on the developed HD and AD models of the lake. Eight 
water quality variables were simulated. These variables are Biological Oxygen Demand (BOD), Dissolved Oxygen (DO), Nitrite (NO2), Nitrate (NO3), Ammonia (NH3), Phosphate (PO4), Chlorophyll-a (Chll_a) and Total Phosphorus (TP). The seasonal measured records of these water quality variables in the lake were used to calibrate the Eco-Lab developed model for the lake. These eight variables are used as indicators for water quality status of Lake Manzala. The calibrated model was simulated for one year (1st Aug. 2010 -1st Aug. 2011). The calibrated model results of this model were used as a base case for this study.

To consider the impacts of the constructed radial channels at the main outlets in the lake, the model bathymetry has been modified according to the new outlets bed levels and dimensions, including the sea basins and the radial channels, Figure (7).

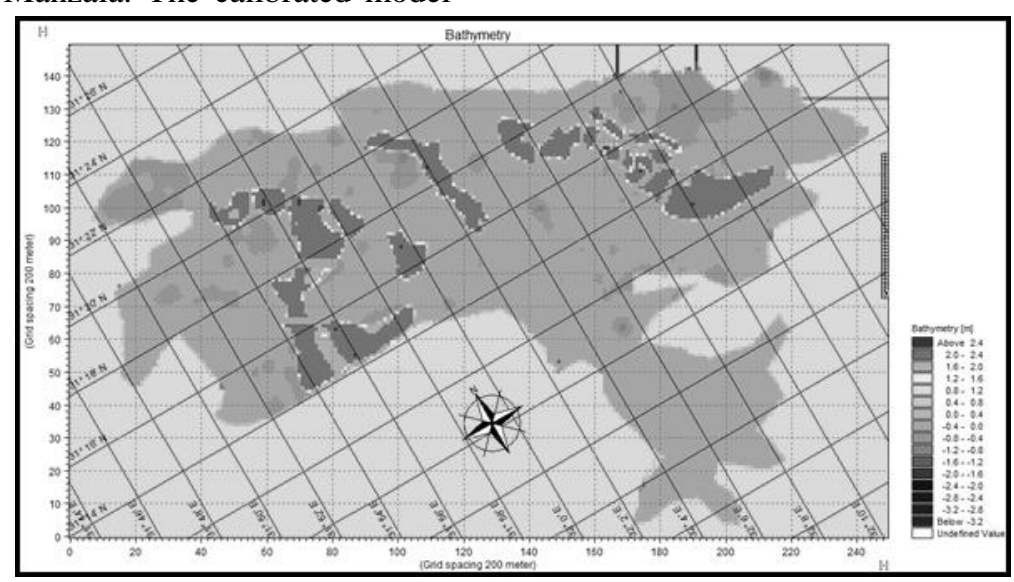

Figure 7: The modified bathymetry for Lake Manzala hydrodynamic and water quality model.

\section{RESULTS AND DISCUSSION}

The calibrated model for Lake Manzala [30] was used as a base case for this work. Modifying of the outlets boundaries has been done to consider the radial channels impacts. The modified model has been run using the same conditions and coefficients of the calibrated model. To quantify any possible changes in the concentrations of the investigated parameters than the base case (the calibrated model) for the same simulation period, a percentage change $(\Delta)$ can be calculated according the following equation:

$\Delta=\frac{\text { average simulated-average calibrated }}{\text { average calibrated }} * 100$

Where average simulated (or calibrated) is the average results of the modified (or calibrated) model for an investigated parameter at a specific station for the simulation period or for the whole lake.

Figures 7 and 8 show the calibrated model against the modified model profiles of the considered water quality parameters for a typical simulation year at different stations, as examples. DO, BOD and Chll_a profiles can be seen in Figure 7, while the nutrient components profiles are shown in Figure 8. The average percentage change can be noticed on the presented figure, its value depends on the location of the station. Station No. 2 will have the greatest impacts due to its location between the two modified outlets. The total percentage ratios for all considered water quality parameters at the eleven record stations can be seen in Figure 9. The results show that a significant improvement can be noticed in the water quality status of the lake. The maximum percentage change can be noticed at Station No. 2 which lies between the two outlets in the northern zone of the lake, as shown in Figure 1. The nutrients components have significant decrease in their concentrations as can be seen in Figure 9. The average decreases ratios than the base case, are about $21 \%, 13 \%, 14 \%, 7 \%$ and $4 \%$ for $\mathrm{PO}_{4}, \mathrm{NH}_{3}, \mathrm{NO}_{2}, \mathrm{NO}_{3}$ and $\mathrm{TP}$, respectively. The average decrease ratio in Chll_a is about $-10 \%$ while the average concentrations ratios for $\mathrm{BOD}$ are increased by about $6 \%$ and $\mathrm{DO}$ average concentrations are increased by about $1 \%$. Significant changes in the investigated water quality parameters can be noticed at Station No.2, where there will be an increase by about $8 \%$ for DO and decreases by about $85 \%, 60 \%, 50 \%$ and $26 \%$ for PO4, BOD, NO3 and Chll_a, respectively. While stations No. 1 and No. 7 will have a decrease in DO by about $1.5 \%$ and an increase by about $80 \%$ in BOD concentrations at Station No.7 is noticed. These odd values at both stations, as can be seen in Figure 9 for most parameters, may return to their location and the flow circulation due to the changes in outlets boundaries. 


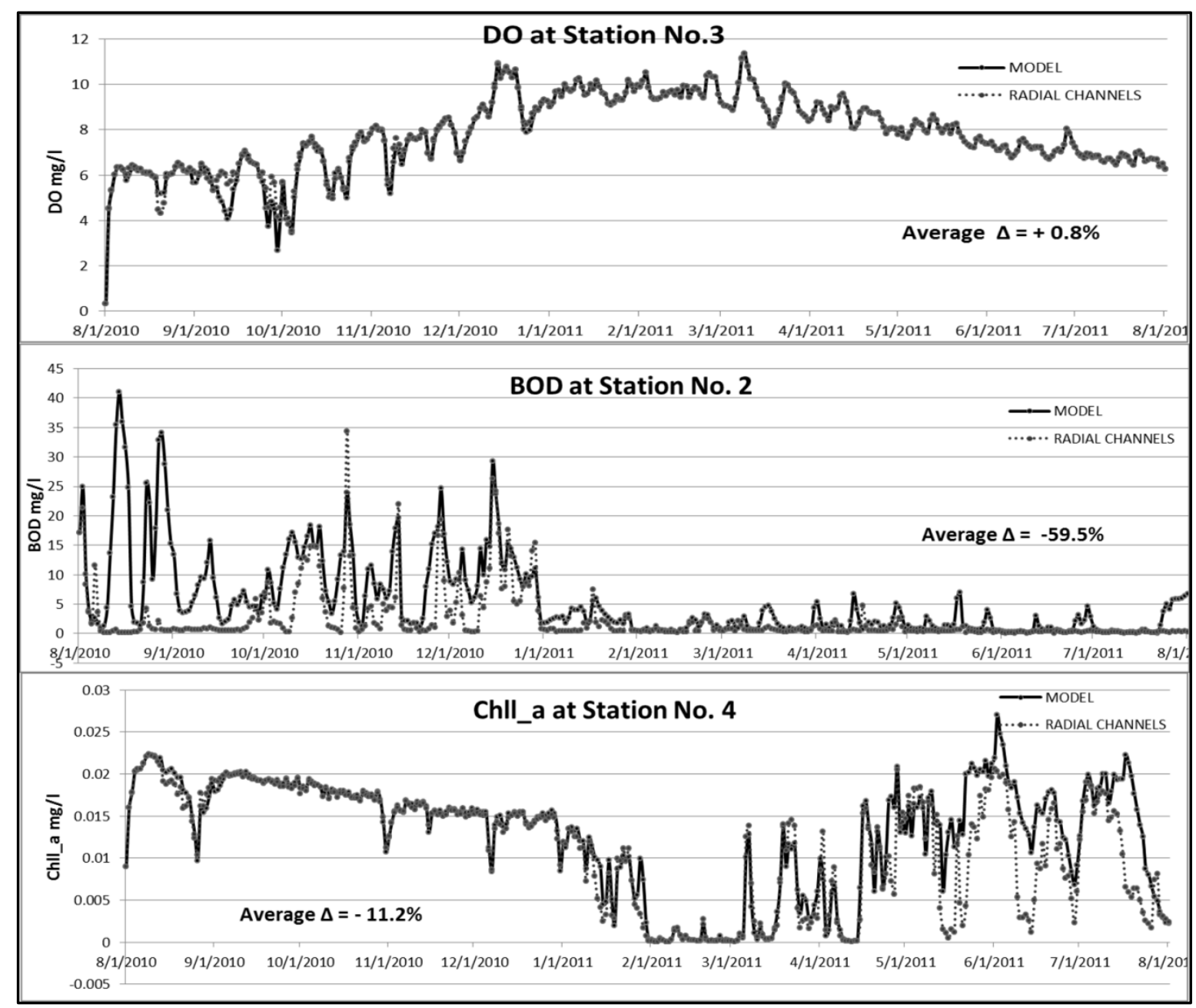

Figure 7: Calibrated and Simulated DO, BOD and Chll_a profiles at different stations in Lake Manzala for a typical year due to Radial Channels scenario.

\section{CONCLUSIONS}

The impacts of Radial Channels Project were investigated on the water quality status of Lake Manzala. A hydrodynamic and water quality model for Lake Manzala was developed and calibrated for a year (Aug. 2010 - July 2011). Water depth, water temperature, salinity and eight water quality parameters (BOD, DO, NO2, NH3, PO4, NO3, Chll_a and TP) were simulated. The simulated profiles closely mimic the field records for all simulated parameters. The calibrated model was modified to investigate the water quality management scenario of Radial Channels Project. Radial Channels will improve the water quality status of the lake, particularly for the northern zone of the lake. An average decrease by about $12 \%$ in the nutrients components concentrations, compared to the calibrated case, while the average decreased ratios are about $21 \%, 13 \%, 14 \%, 7 \%, 4 \%$ and $10 \%$ for $\mathrm{PO}_{4}, \mathrm{NH}_{3}$, $\mathrm{NO}_{2}, \mathrm{NO}_{3}$, TP and Chll_a, respectively.

According to the results, it is clear that the impact of Radial Channels Project on water quality status of Lake Manzala is good; this scenario allows the sea-lake exchange to be better through the lake outlets, which participates in the water quality status improvement. However, other scenarios such as water treatment plants on the drains outlets should be investigated and implemented, in addition to the current scenario.

The developed model is being used to investigate other water quality management scenarios such as diversion of Bahr El-Baqar drain from Lake Manzala. This work supports the decision makers to take action and initiate such water quality management scenarios for Lake Manzala. 


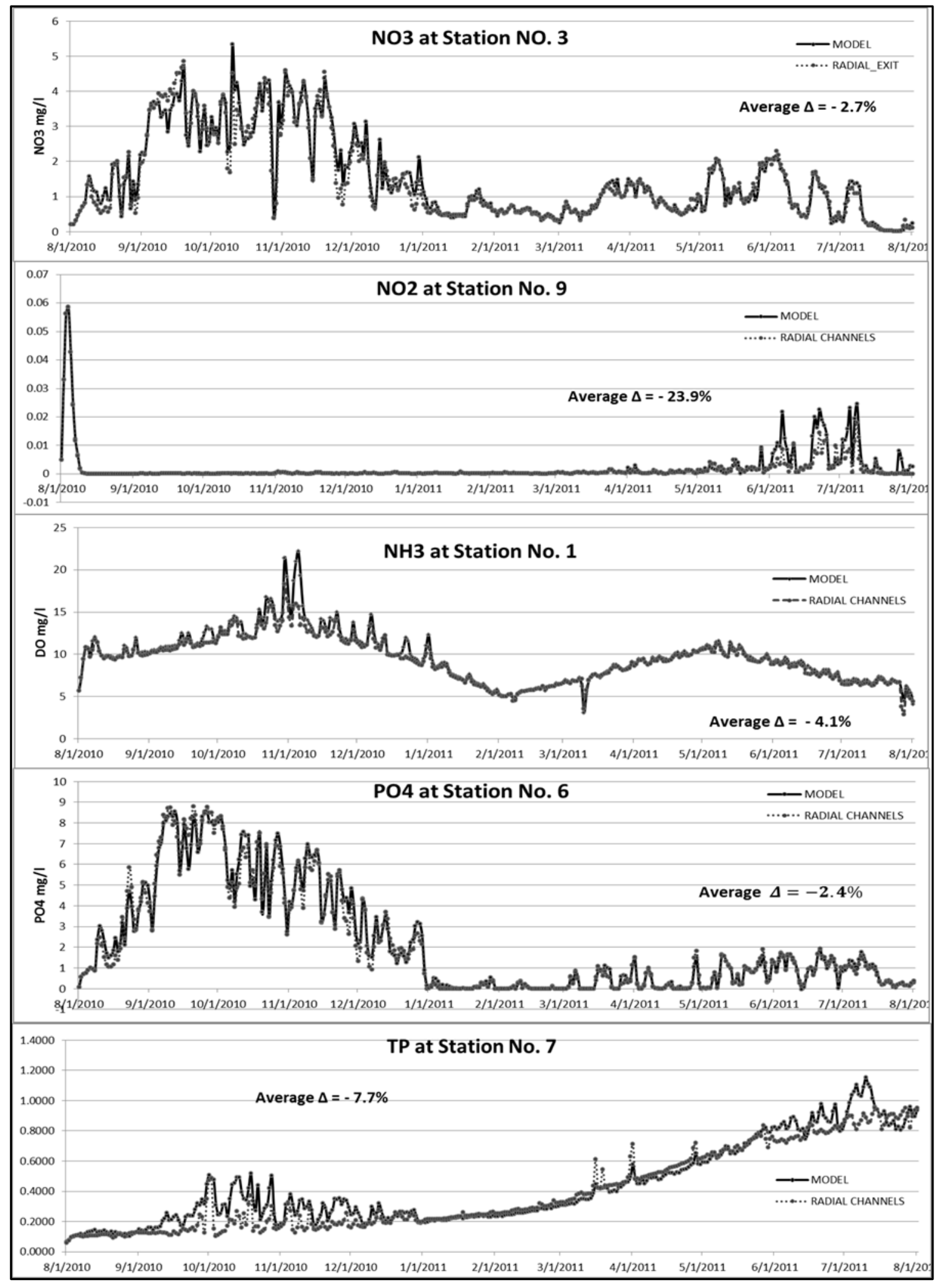

Figure 8: Calibrated and Simulated nutrients components profiles at different stations in Lake Manzala for a typical year due to Radial Channels scenario 


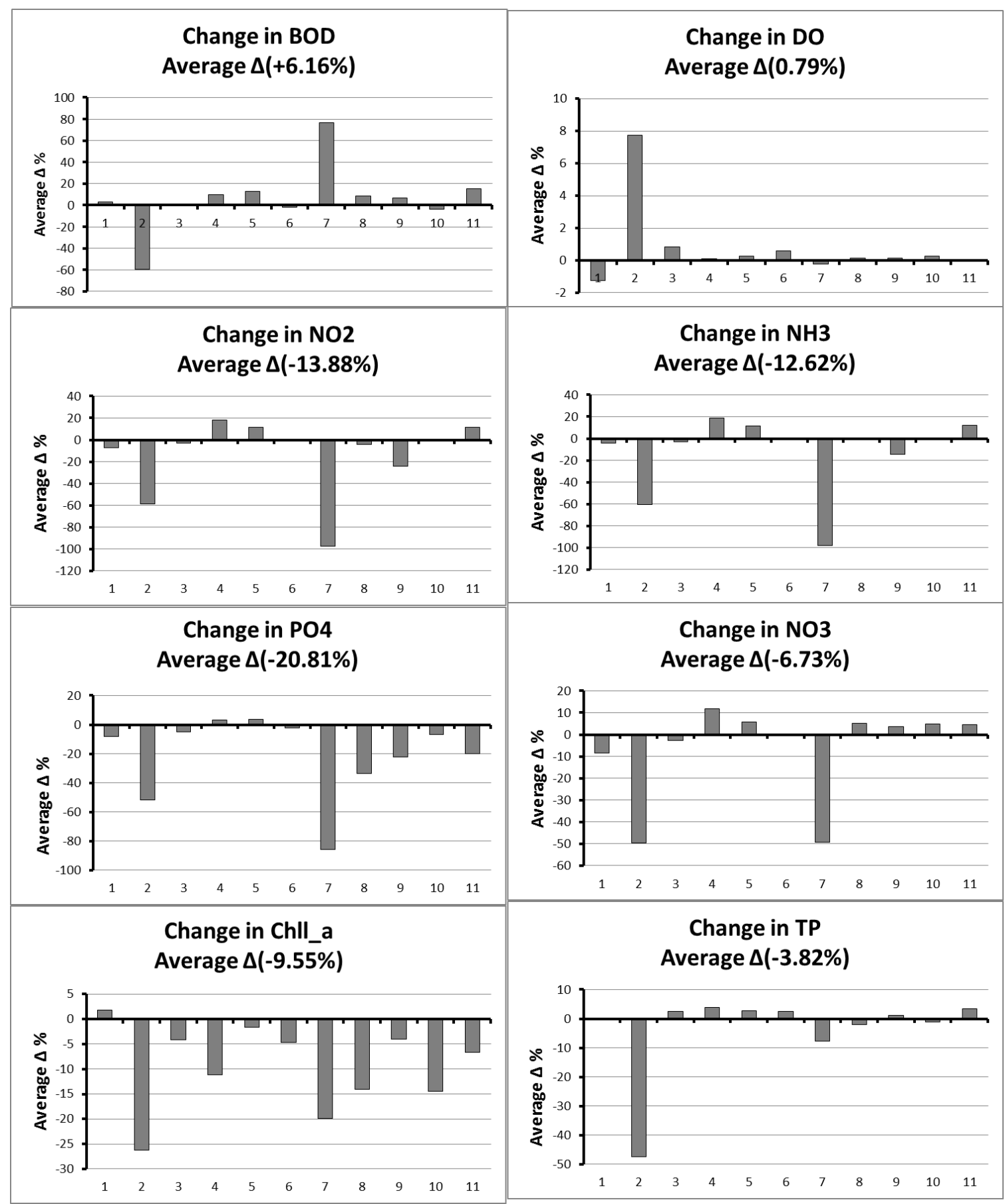

Figure 9: Percentage change ratios for different water quality parameters at the considered stations in Lake Manzala due to Radial Channels Project

\section{REFERENCES}

[1] Akman, Y., O. Ketenoglu, H. Evren, L. Kurt and S. Düzenli (2000). Environmental Pollution, Environmental Biology. 1st Edn. Palme Publication, Ankara.

[2] Khalil MT (1990). The physical and chemical environment of Lake Manzala, Egypt. Hydrobiologia $196 \quad$ (3):193-199. doi:10.1007/bf00006132.

[3] GAFRD (2014). Fish Statistics Yearbook 2013. General Authority for Fish Resources Development (GAFRD), Cairo, Egypt.
[4] Thompson JR, Flower RJ, Ramdani M (2009). Hydrological characteristics of three North African coastal lagoons: insights from the MELMARINA project. Hydrobiologia 622 (1):45-84. doi:10.1007/s10750-008-9680-x.

[5] Salah, A. T. (2007). Environmental perspectives of the port said area. In: SMAP (ed.) Plan of action for integrated coastal zone management in the area of Port Said, Egypt.

[6] Elshemy M., Khadr M., Atta Y. and Ahmed A (2016). Hydrodynamic and Water Quality Modeling of Lake Manzala (Egypt) Under Data Scarcity. Environ Earth Sci 75:1329. Doi: 10.1007/s 12665-016-6136-x. 
[7] Bishai, H. M. and Yosef, S. F. (1977). Some Aspects on the hydrography, physio-chemical characteristics and fisheries of Lake Manzala. Bull. Inst. Ocean \& Fish., A.R.E., Vol. 7, pp: 31-58

[8] Ramdani, M., Elkhiati, N., Flower, R. J., Thompson, J. R., Chouba, L., Kariem, M. M., Ayache, F. \& Ahmed, M. H. (2009). Environmental influences on the qualitative and quantitative composition of phytoplankton and zooplankton in North African coastal lagoons. Hydrobiologia, 622, 113-131.

[9] Hamed YA, Abdelmoneim TS, ElKiki M, Hassan M, Berndtsson R (2013). Assessment of Heavy Metals Pollution and Microbial Contamination in Water, Sediments and Fish of Lake Manzala, Egypt. Life Science journal 10 (1):86-99.

[10] Eman Abdel Ghaffar Hasan. (2008). Prediction of Salt Load Flowing to Lake El Manzala Using Artificial Neural Networks The 3rd International Conference on Water Resources and Arid Environments and the 1st Arab Water Forum

[11] Bahnasawy, M.; A. Khidr and N. Dheina. 2011.Assessment of heavy metal concentrations in water, plankton, and fish of Lake Manzala, Egypt. Turk J. Zool, 35(2):271-280.

[12] Flower RJ (2001). Change, stress, sustainability and aquatic ecosystem resilience in North African wetland lakes during the 20th century: An introduction to integrated biodiversity studies within the CASSARINA Project. Aquatic Ecology $35 \quad$ (3-4):261-280. doi:10.1023/a:1011978420737

[13] Flower RJ, Thompson JR (2009). integrated hydro-ecological studies in the MELMARINA Project: monitoring and modelling coastal lagoons - making management tools for aquatic resources in North. Hydrobiologia 622 (1):3-14. doi:10.1007/s10750-008-9674-8.

[14] Rasmussen E. K., Petersen O. S., Thompson J. R., Flower R. J. and Ahmed M. H. (2009). Hydrodynamic-ecological model analyses of the water quality of Lake Manzala (Nile Delta, Northern Egypt) Hydrobiologia, 622:195-220. DOI 10.1007/s10750-008-9683-7.

[15] Bek Ma, Lowndes IS, Hargreaves DM (2011). The application of a validated hydrodynamic model to improve the water management of an Egyptian shallow water coastal lake. In: David A. Swayne Wyaavartf (Ed.) iEMSs, Ottawa, Canada, 2010 2010. iEMSs, pp 1-9

[16] M. Elshemy \& M. Khadr (2015) Hydrodynamic Impacts of Egyptian Costal Lakes due to Climate Change - Example MANZALA Lake. International Water Technology Journal, IWTJ. Vol. 5 -No.3, September 2015.

[17] Rashad HM, Abdel-Azeem AM (2010). Lake Manzala, Egypt: A Bibliography. Assiut Univ. J of Botany 39 (1):253-289.
[18] El-Bayomy JM (1994). Lake Manzala Area "Geomorphological Study". MSc Thesis, Faculty of Arts, Cairo University, Cairo.

[19] Hossam M. Moghazy (2018). "Lake Manzala, Ambitions and Challenges", presentation in "Lake Pollution and Shore Protection Between the Present Situation and Future Vision", 2018, Faculty of Engineering, Tanta University, Egypt (unpublished work).

[20] Weather Underground, www.wunderground.com (accessed in Sep. 2018).

[21] Info-space,http://meteo.infospace.ru/climate/html (accessed in Sep. 2018).

[22] Daly R, Wallace T River Murray (2015). Channel Environmental Water Requirements. In: Goyder Institute Water Research Conference 2015, Australia.

[23] Kaiglová J, Langhammer J, Ji` P, Janský B, Chalupová D (2014). Numerical modelling of fine-grained sediments remobilization in heavily polluted streams. Case study: Elbe and Bílina River, Czech Republic. Paper presented at the EGU General Assembly 2014, Vienna, Austria.

[24] Jusoh WHW, Tangang F, Juneng L, Hamid MRA (2014) Numerical modeling of hydrodynamic in southwestern Johor, Malaysia. Paper presented at the 2014 UKM FST Postgraduate Colloquium, Selangor, Malaysia.

[25] Assar W, Elshemy M, B.Zeidan (2015) Water Quality Modeling for Lake Burullus, Egypt, Part I: Model Calibration. Mansoura Engineering Journal 40 (2).

[26] Petersen G, Fohrer N (2010) Two-dimensional numerical assessment of the hydrodynamics of the Nile swamps in southern Sudan. Hydrological Sciences Journal 55 (1):17-26. doi:10.1080/02626660903525252.

[27] Elshemy M (2017). "Environmental and Climatic Implications of Lake Manzala, Egypt: Modeling and Assessment". In: The Handbook of Environmental Chemistry. Springer, Berlin, Heidelberg,

[28] M. Elshemy, B. A. Zeidan, W. Assar. "Water Quality Mitigation Scenarios for Burullus Coastal Lake, Egypt". Proceedings of the "Sixth International Conference on Estuaries and Coasts" (ICEC-2018), August 20 - 23, 2018, Caen, France.

[29] A. Shalby, M. Elshemy, B. A. Zeidan. "Climate Change Impacts on Lake Burullus, Coastal Lagoon (Egypt)". Proceedings of the "Sixth International Conference on Estuaries and Coasts" (ICEC-2018), August 20 - 23, 2018, Caen, France.

[30] A. A. Hassan, A. El-Hamaimi, A. Mirdan and M. Elshemy (2018). "Impact Assessment of Bahr El-Baqar Diversion Project on Water Quality Status in Lake Manzala, Eastern Nile Delta, Egypt". The International Workshop on "Linking Water Security to the Sustainable Development Goals", University of São Paulo, Brazil. 29 $9^{\text {th }}$ August to $1^{\text {st }}$ September 2018. 


\section{تقييم أثر مشروع القتوات الاشعاعية على حالة جودة المياة

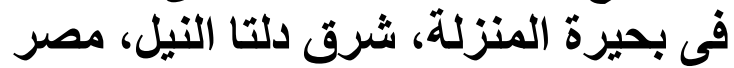

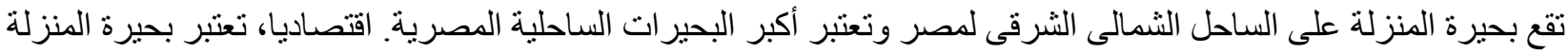

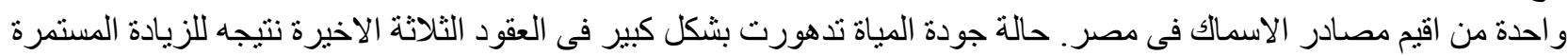

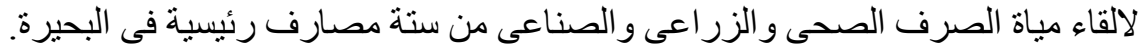

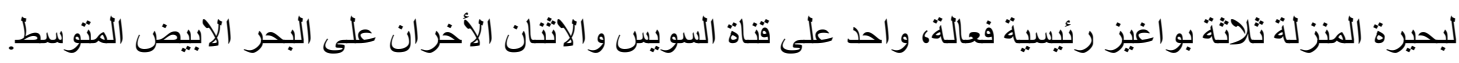

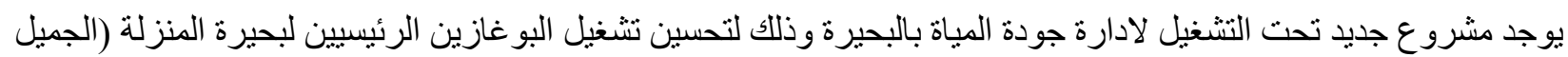

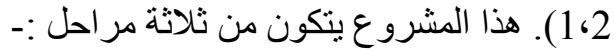

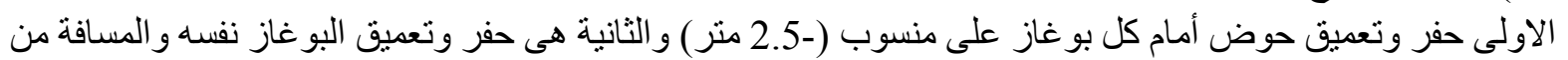

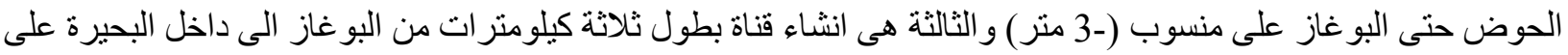

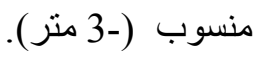
فى هذا البحث تم بناء نموذج لهيدروديناميكية وجودة المياة بالبحيرة باستخدام برنامج ( مايك 21 ) حيث تم نمذجة ثمانية عناصر

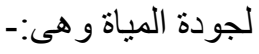

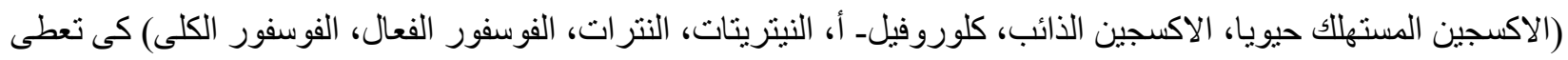

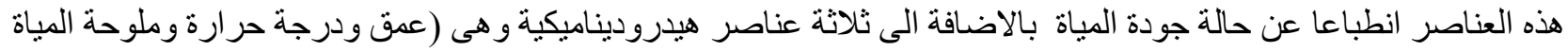

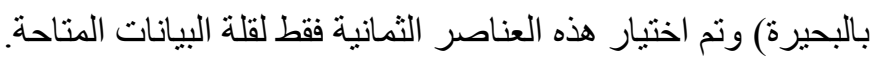

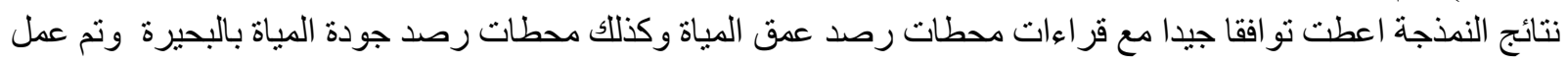

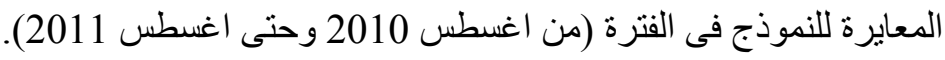

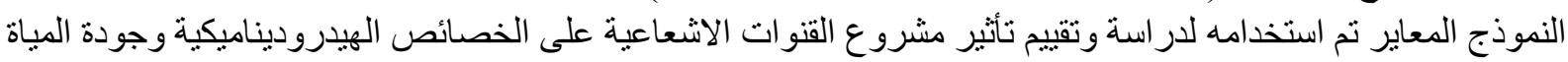

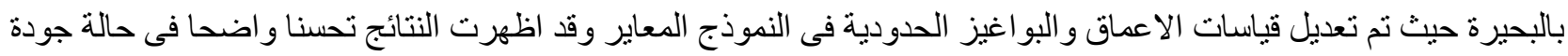

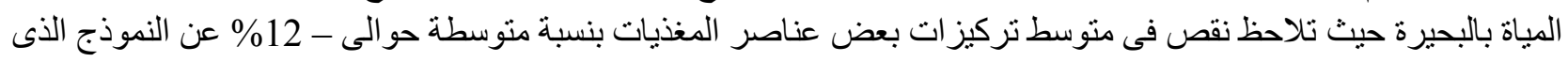

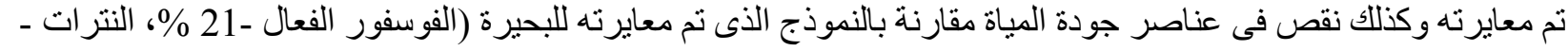

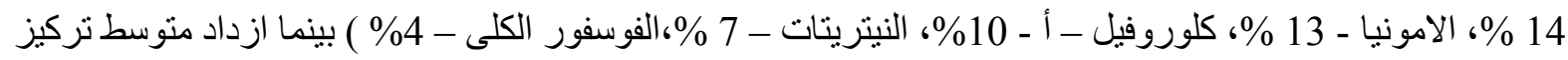

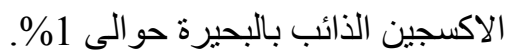
من النتائج يتضح ان مشروع القنو ات الاشعاعية جيدا لتحسين جودة المياة بالبحيرة حيث انه سيزيد من تبادل المياة بين البحيرة و البحر. سوف يتم استخدام النموذج المعاير فى اختبار وتقييم بعض سيناريو هات تحسين جودة المياة بالبحيرة. 